ISSN: 2224-0616

Int. J . Agril. Res. Innov. \& Tech. 3 (1): 47-51, J une, 2013 Available online at http:// www.ijarit.webs.com

\title{
COMBINED EFFECT OF ORGANIC MANURE AND POTASSIUM ON GROWTH AND YIELD OF ONION CV. BARI PIAZ-I
}

\author{
H.K. Barman', M.N. Siddiqui' ${ }^{2}$ M.A.Siddique', M.S. Roni ${ }^{3}$ and M. Nuruzzaman1
}

Received 27 April 2013, Revised 3 June 2013, Accepted 20 June 2013, Published online 30 June 2013

\begin{abstract}
An experiment was conducted to find out the combined effect of cowdung and potassium on the growth and yield of onion cv. BARI piaz-I at Horticulture Farm, Bangladesh Agricultural University, Mymensingh during the period from December 2010 to March 2011. The experiment was laid out in a randomized complete block design with three replications. The two factors experiment had four levels of cowdung, viz., 0, 5, 10 and 20 tons ha-1 and four levels of potassium, viz. 0, 50, 150 and $250 \mathrm{~kg} \mathrm{~K} \mathrm{ha}^{-1}$. Doses of cowdung and potassium showed significant variation in respect of all the parameters studied. The combination of 10

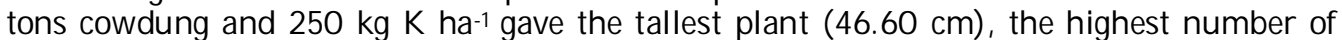
leaves plant ${ }^{-1}(6.40)$, the highest length of bulb $(3.27 \mathrm{~cm})$, the highest diameter of bulb (4.83 $\mathrm{cm}$ ), individual weight of bulb (51.23 g), dry matter content (12.66\%) and yield of bulb ha-1 (12.83 tons); whereas the control treatment gave the shortest plant $(38.15 \mathrm{~cm})$, lowest number of leaves plant ${ }^{-1}$ (5.68), diameter of bulb (3.41), individual weight of bulb (35.65g) and gave lowest bulb yield ha- ${ }^{-1}$ (9.16 tons).
\end{abstract}

Keywords: Cowdung, Potassium, Onion, Bulb Yield

${ }^{1}$ Department of Horticulture, Bangladesh Agricultural University, Mymensingh, Bangladesh

${ }^{2}$ Department of Biochemistry and Molecular Biology, Bangabandhu Sheikh Mujibur Rahman Agricultural University, Gazipur-1706, Bangladesh

${ }^{3}$ Department of Horticulture, Bangabandhu Sheikh Mujibur Rahman Agricultural University, Gazipur-1706, Bangladesh

*Corresponding author's email: nuralam_hstu@yahoo.com (M.N. Siddiqui)

\section{Introduction}

Onion (Allium cepa L.) belonging to the family Alliaceae is one of the most important spice as well as vegetables crops in the world including Bangladesh. Among the spices crops grown in Bangladesh onion ranks top in respect of production and second in respect of area. It is a short duration and quick growing having various uses such as vegetables, spices and medicinal. The main edible portion is the bulb, which is a modified organ consisting of thickened fleshy scale leaves and stem plate (Jones and Mann, 1963). In Bangladesh onion has been an integral part of the people's daily diet and its use is very common in almost all food preparations (Hossain and Islam, 1994). Medicinal value of this spice crop is helpful for human being and it has preservative.

The demand of onion bulbs and its seeds are increasing with the ever increasing population. To meet the national requirement, Bangladesh officially imported 47 thousand tones of onion in 1999 with a cost of about US\$ 10.3 million. The total production of onion in Bangladesh in far less than the quantity required. The total requirement is 1030 thousand metric tons and 330 thousand metric tons is imported annually (Anonymous,
2005). There are many causes for such limited production, which include production of onion only in the winter season and use of sub-optimal production inputs at the farmers' level. As a result, huge amount of onion bulb is imported and smuggled in from neighboring countries like India, Myanmar and Pakistan.

Onion production is greatly influenced by agronomic practices (Mondal et al., 1986). The production of onion in Bangladesh can be increased either by extending the land area under cultivation or by increasing the yield of the crop. The hectare ${ }^{1}$ yield of onion can be increased by efficient use of manures and fertilizers (Katwale and Saraf, 1994). Organic manure improves soil physical chemical properties that are important for plant growth (Synman et al., 1998). Organic fertilizers has positive effect on root growth by improving the root rizosfer conditions (structure, humidity, etc.) and also plant growth is encouraged by increasing the population of microorganisms (Shaheen et al., 2007). Organic fertilizers contain plant nutrients. Organic acids which occur in decomposition increases the benefits of nutrients (Anonymous, 2010). Cowdung is important organic manure in Bangladesh. The farmers of our country today is 
burned as fuel it and is this lost to agriculture. Cowdung manure may be bulky (nutrient contents are very low per unit volume) and it improve physical conditions of the soil and supplies N-P-K and other nutrients to plants. Now a day's gradual deficiency in soil organic matter and reduced yield of crop are an alarming factor and burning issue for the farmers and agriculturists.

Judicial application of organic and inorganic fertilizers is important for the production of onion. Among the nutrients, potassium plays the most important role for photosynthetic activity of leaf, as it helps in translocation of food (Rai, 1981). Potassium helps in root development, and exerts a balancing role in multi nutrient fertilizer application (Brady, 1995). Among the yield contributing factors, application of proper doses of potassium is of great importance (Magruder and Allard, 1937; Sotomayer, 1975). The higher doses of potassium showed positive effect to attain lower percentage of rotten bulb and weight loss (Dilruba, 2001). Adequate potassium levels are especially important in improving bulb quality and storage life (Ali et al., 1994).

Considering the above points, the main objective of this present experiment was to study the effect of different levels of organic manures and potassium on the growth and bulb yield of onion cv BARI-I plants.

\section{Materials and Methods}

The experiment work was conducted at the Horticulture Farm of Bangladesh Agricultural University, Mymensingh, during the period from December, 2010 to March, 2011 in an attempt to evaluate the effect of different levels of cowdung and potassium on growth and yield of onion cv. BARI piaz-I. The soil of experiment area was medium high in topography and sandy loam in texture belonging to the Old Brahmaputra Flood Plain Alluvial Tract under the AEZ number 9 (UNDP, 1988). The research work was carried out with onion variety BARI piaz-I. The seeds were collected from the Spices Research Centre of Bangladesh Agricultural Research Institute (BARI), Gazipur. The experiment was consisted of 16 treatment combinations and was laid out in the Randomized Complete Block Design with three replications. An area of 153 square meter of uniform fertility with good irrigation and drainage channels was divided into three equal blocks, representing the replications. A $75 \mathrm{~cm}$ space between the blocks and $50 \mathrm{~cm}$ between the plots was provided. The size of a unit plot was $1.2 \mathrm{~m} \mathrm{X} 1.0 \mathrm{~m}$. The experiment had two factors and was designed to study the effect of different cowdung and potassium levels on growth and yield of onion cV. BARI piaz-I). The experiment consisted of the following treatments:

\section{Factor A: four levels of cowdung}

$\mathrm{C}_{0}: 0$ ton cowdung ha- ${ }^{-1}$ (control)

$\mathrm{C}_{1}: 5$ ton cowdung ha-1

$\mathrm{C}_{2}: 10$ ton cowdung ha ${ }^{-1}$

$\mathrm{C}_{3}: 20$ ton cowdung ha- 1

\section{Factor B: four levels of potassium (K)}

$\mathrm{K}_{0}: 0 \mathrm{~kg} \mathrm{Kha}^{-1}$ (control)

$\mathrm{K}_{1}: 50 \mathrm{~kg} \mathrm{Kha}^{-1}$

$\mathrm{K}_{2}: 150 \mathrm{~kg} \mathrm{Kha}^{-1}$

$\mathrm{K}_{3}: 250 \mathrm{~kg} \mathrm{~K} \mathrm{ha}^{-1}$

In this study, manures and fertilizers were applied according to the experimental treatments. The seedlings were always kept under careful observation. Necessary intercultural operations were done throughout the cropping season for better growth and development of the plants. The crop was harvested when $75 \%$ of the tops had fallen over (Shalalby et al., 1991). The data on plant height, number of leaves plant ${ }^{-1}$, length of bulb, diameter of bulb, individual weight of bulb, and dry matter percentage of bulb and yield of bulb hectare ${ }^{-1}$ were recorded. The percentage of bulb dry matter was calculated by the following formula:

$\%$ Dry matter of bulb $=\frac{\text { Constant weight of bulb }}{\text { Fresh weight of bulb }} \times 100$

The collected data were statistically analyzed using MSTAT software. Difference (LSD) taking the probability level $5 \%$ and $1 \%$ as the minimum unit of significance and where higher levels of significance were found, they were indicated in results (Gomez and Gomez, 1984).

\section{Results and Discussion}

\section{Plant height}

The combined effect of cowdung and potassium was statistically significant. The tallest plant $(46.60 \mathrm{~cm})$ was observed from the treatment combination of 10 tons cowdung ha-1 and $250 \mathrm{~kg}$ $\mathrm{K} \mathrm{ha}^{-1}$ the shortest plant $(39.77 \mathrm{~cm})$ was obtained from the control dose. The height of plant increased gradually with the increased level of cowdung up to 10 tons ha- ${ }^{-1}$ and potassium up to $250 \mathrm{~kg} \mathrm{~K} \mathrm{ha}^{-1}$ plant height will be increased (Table 1). Our findings were full agreement with the result of Singh and Dhankhar (1988).

\section{Number of leaves}

The combined effect of cowdung and potassium on the number of leaves plant ${ }^{1}$ was significant (Table 1). The maximum number of leaves plant-1 (6.40) was recorded from the treatment 
combination 20 tons cowdung ha-1 with $250 \mathrm{~kg} \mathrm{~K}^{-1}$ ha $^{-1}$, while the minimum number of plant leaves plant $^{-1}$ (5.68) was obtained from the treatment combination of 0 tons cowdung ha- ${ }^{-1}$ with $0 \mathrm{~kg} \mathrm{~K}$ ha $^{-1}$ at 70 DAT (Table 1). The result points out that the number of leaves plant ${ }^{-1}$ was highest (6.40) with the treatment containing the highest dose of cowdung 20 tons ha-1 and $250 \mathrm{~kg} \mathrm{~K}$ ha $^{-1}$ respectively. Singh and Dhankhar (1989) also observed similar results. From this study, it was found that the number of leaves plant $^{-1}$ was directly related with the application of optimum levels of cowdung and potassium.

Table 1. Combined effect of cowdung and potassium on plant height and number of leaves plant-1

\begin{tabular}{|c|c|c|c|c|c|c|c|c|c|c|c|c|}
\hline \multirow[t]{2}{*}{ Treatment } & \multicolumn{6}{|c|}{ Plant height $(\mathrm{cm})$ at different DAT } & \multicolumn{6}{|c|}{ No. of leaves plant ${ }^{1}$ at different DAT } \\
\hline & 20 & 30 & 40 & 50 & 60 & 70 & 20 & 30 & 40 & 50 & 60 & 70 \\
\hline $\mathrm{C}_{0} \mathrm{~K}_{0}$ & 7.20 & 11.37 & 20.16 & 24.48 & 30.70 & 38.15 & 1.81 & 2.10 & 3.20 & 3.22 & 3.58 & 5.68 \\
\hline $\mathrm{C}_{0} \mathrm{~K}_{1}$ & 7.62 & 12.23 & 21.56 & 25.48 & 32.06 & 39.77 & 2.00 & 2.20 & 3.10 & 3.36 & 3.76 & 5.90 \\
\hline $\mathrm{C}_{0} \mathrm{~K}_{2}$ & 7.54 & 12.23 & 21.37 & 25.90 & 31.45 & 39.85 & 1.98 & 2.20 & 3.20 & 3.33 & 3.73 & 5.86 \\
\hline $\mathrm{C}_{0} \mathrm{~K}_{3}$ & 7.63 & 12.34 & 21.95 & 25.98 & 32.17 & 40.09 & 2.00 & 2.23 & 3.26 & 3.36 & 3.76 & 5.93 \\
\hline $\mathrm{C}_{1} \mathrm{~K}_{0}$ & 7.68 & 12.40 & 21.99 & 26.14 & 32.55 & 41.19 & 2.00 & 2.23 & 3.24 & 3.36 & 3.86 & 5.90 \\
\hline $\mathrm{C}_{1} \mathrm{~K}_{1}$ & 7.76 & 12.46 & 22.64 & 26.37 & 33.06 & 41.72 & 2.03 & 2.26 & 3.28 & 3.36 & 3.93 & 5.96 \\
\hline $\mathrm{C}_{1} K_{2}$ & 7.68 & 12.49 & 22.24 & 26.68 & 32.93 & 41.38 & 2.00 & 2.26 & 3.26 & 3.40 & 3.90 & 5.96 \\
\hline $\mathrm{C}_{1} \mathrm{~K}_{3}$ & 7.89 & 12.51 & 22.66 & 26.74 & 33.12 & 41.90 & 2.03 & 2.28 & 3.30 & 3.40 & 3.93 & 6.03 \\
\hline $\mathrm{C}_{2} \mathrm{~K}_{0}$ & 7.70 & 12.40 & 22.14 & 26.21 & 32.41 & 40.64 & 2.00 & 2.23 & 3.20 & 3.36 & 3.83 & 5.93 \\
\hline $\mathrm{C}_{2} \mathrm{~K}_{1}$ & 7.79 & 12.54 & 22.63 & 26.51 & 32.60 & 41.77 & 2.00 & 2.26 & 3.28 & 3.40 & 3.83 & 6.00 \\
\hline $\mathrm{C}_{2} \mathrm{~K}_{2}$ & 7.86 & 12.49 & 22.19 & 26.31 & 32.95 & 41.59 & 2.03 & 2.26 & 3.23 & 3.36 & 3.86 & 5.96 \\
\hline $\mathrm{C}_{2} \mathrm{~K}_{3}$ & 7.92 & 12.59 & 22.79 & 26.56 & 33.00 & 46.60 & 2.03 & 2.30 & 3.26 & 3.40 & 3.86 & 6.40 \\
\hline $\mathrm{C}_{3} \mathrm{~K}_{0}$ & 7.92 & 12.66 & 22.88 & 26.87 & 33.40 & 42.76 & 2.04 & 2.30 & 3.33 & 3.46 & 3.90 & 6.06 \\
\hline $\mathrm{C}_{3} \mathrm{~K}_{1}$ & 8.14 & 12.69 & 23.00 & 26.94 & 33.57 & 42.89 & 2.06 & 2.33 & 3.33 & 3.43 & 3.96 & 6.06 \\
\hline $\mathrm{C}_{3} \mathrm{~K}_{2}$ & 8.20 & 12.79 & 23.00 & 27.04 & 33.86 & 42.99 & 2.08 & 2.36 & 3.36 & 3.46 & 4.00 & 6.10 \\
\hline $\mathrm{C}_{3} \mathrm{~K}_{3}$ & 8.67 & 13.65 & 25.04 & 29.07 & 35.74 & 41.92 & 2.41 & 2.45 & 3.47 & 3.58 & 4.25 & 6.00 \\
\hline LSD at 5\% & 0.08 & 0.14 & 0.10 & 0.13 & 0.27 & 0.29 & 0.01 & 0.01 & 0.01 & 0.01 & 0.03 & 0.04 \\
\hline LSD at $1 \%$ & 0.11 & 0.18 & 0.13 & 0.17 & 0.37 & 0.39 & 0.02 & 0.01 & 0.02 & 0.02 & 0.04 & 0.06 \\
\hline $\begin{array}{l}\text { Level of } \\
\text { significance }\end{array}$ & $* *$ & $* *$ & $* *$ & $* *$ & $* *$ & $* *$ & $* *$ & ** & $* *$ & $* *$ & $* *$ & $*$ \\
\hline $\begin{array}{l}\mathrm{C}_{0}=0 \text { ton } \mathrm{Co} \\
\mathrm{C}_{1}=5 \text { ton } \mathrm{co} \\
\mathrm{C}_{2}=10 \text { ton } \\
\mathrm{C}_{3}=20 \text { ton } \mathrm{c}\end{array}$ & ung & & $\begin{array}{l}\mathrm{K}_{0}= \\
\mathrm{K}_{1}= \\
\mathrm{K}_{2}= \\
\mathrm{K}_{3}=\end{array}$ & $50 \mathrm{~kg}$ & $\begin{array}{l}\mathrm{a}^{-1} \\
\mathrm{ha}^{-1} \\
\mathrm{ha}^{-1}\end{array}$ & & ifice & & & roba & & \\
\hline
\end{tabular}

\section{Length of bulb}

The effect of cowdung and potassium combinedly showed significant variation with respect of bulb length. The maximum bulb length $(3.27 \mathrm{~cm})$ was obtained from the plant that received 10 tons cowdung ha-1 and $250 \mathrm{~kg} \mathrm{~K}^{-1}$. The lowest bulb length $(2.80 \mathrm{~cm})$ was found from the control (Table 2).

\section{Diameter of bulb}

There was non-significant variation due to the combination effect of cowdung and potassium application. The diameters of the bulbs were varied from $3.41 \mathrm{~cm}$ to $4.83 \mathrm{~cm}$. The maximum diameter $(4.83 \mathrm{~cm})$ was found from the treatment combination of 10 tons cowdung ha-1 and $250 \mathrm{~kg} \mathrm{~K} \mathrm{ha}^{-1}$ that was statistically different from the other combination. The lowest bulb length $(3.41 \mathrm{~cm})$ was found from the control treatment (Table 2). 
Table 2. Combined effect of cowdung and potassium on length of bulb, diameter of bulb, individual weight of bulb, dry matter \% of bulb, yield of bulb hectare ${ }^{-1}$

\begin{tabular}{llllll}
\hline Treatment & $\begin{array}{l}\text { Length of bulb } \\
(\mathrm{cm})\end{array}$ & $\begin{array}{l}\text { Diameter of } \\
\text { bulb } \\
(\mathrm{cm})\end{array}$ & $\begin{array}{l}\text { Individual } \\
\text { weight of bulb } \\
(\mathrm{g})\end{array}$ & $\begin{array}{l}\text { Dry matter of } \\
\text { bulb } \\
(\%)\end{array}$ & $\begin{array}{l}\text { Yield of bulb } \\
\text { hectare }^{-1}\end{array}$ \\
\hline $\mathrm{C}_{0} \mathrm{~K}_{0}$ & 2.80 & 3.41 & 35.65 & 11.26 & 9.16 \\
$\mathrm{C}_{0} \mathrm{~K}_{1}$ & 2.88 & 3.71 & 39.63 & 11.33 & 9.41 \\
$\mathrm{C}_{0} \mathrm{~K}_{2}$ & 2.57 & 3.68 & 38.70 & 11.41 & 11.16 \\
$\mathrm{C}_{0} \mathrm{~K}_{3}$ & 2.87 & 3.78 & 40.00 & 11.50 & 9.66 \\
$\mathrm{C}_{1} \mathrm{~K}_{0}$ & 2.97 & 3.80 & 40.23 & 11.55 & 9.75 \\
$\mathrm{C}_{1} \mathrm{~K}_{1}$ & 2.88 & 3.86 & 41.46 & 11.61 & 10.83 \\
$\mathrm{C}_{1} \mathrm{~K}_{2}$ & 2.81 & 3.84 & 41.06 & 11.61 & 10.50 \\
$\mathrm{C}_{1} \mathrm{~K}_{3}$ & 2.97 & 3.92 & 42.23 & 11.96 & 10.91 \\
$\mathrm{C}_{2} \mathrm{~K}_{0}$ & 3.01 & 4.30 & 43.10 & 11.83 & 11.08 \\
$\mathrm{C}_{2} \mathrm{~K}_{1}$ & 2.99 & 4.37 & 45.30 & 12.21 & 11.75 \\
$\mathrm{C}_{2} \mathrm{~K}_{2}$ & 3.04 & 4.36 & 43.20 & 12.05 & 11.33 \\
$\mathrm{C}_{2} \mathrm{~K}_{3}$ & 3.27 & 4.83 & 51.23 & 12.66 & 12.83 \\
$\mathrm{C}_{3} \mathrm{~K}_{0}$ & 2.92 & 3.88 & 40.50 & 11.66 & 10.35 \\
$\mathrm{C}_{3} \mathrm{~K}_{1}$ & 2.88 & 4.12 & 41.90 & 11.81 & 10.50 \\
$\mathrm{C}_{3} \mathrm{~K}_{2}$ & 2.88 & 3.92 & 41.73 & 11.77 & 10.08 \\
$\mathrm{C}_{3} \mathrm{~K}_{3}$ & 2.87 & 4.13 & 42.10 & 11.88 & 10.83 \\
$\mathrm{LSD}_{2}$ at $5 \%$ & 0.03 & & 0.99 & 0.07 & 0.02 \\
$\mathrm{LSD}_{2}$ at $1 \%$ & 0.05 & & 1.32 & 0.10 & 0.03 \\
$\mathrm{Level}_{2}$ of & $* *$ & $\mathrm{NS}$ & $* *$ & $* *$ & $* *$ \\
significance & & & & & \\
\hline & & & & & \\
\hline
\end{tabular}

NS $=$ Not significant,$* *=$ Significant at $1 \%$ level of probability,$*=$ Significant at $5 \%$ level of probability

\section{Individual weight of bulb}

The combined effect of cowdung and potassium had significant effect on the individual weight of bulb as well as significant influence on their interaction effect. However, the highest bulb weight $(51.23 \mathrm{~g})$ was found from the treatment combination of 10 tons cowdung ha-1 and $250 \mathrm{~kg}$ $\mathrm{K} \mathrm{ha}^{-1}$ and the lowest (35.65 g) was observed from control (Table 2). This result is an agreement with that of Singh and Dhankhar (1988) who found similar result on effect of cowdung and potassium on fresh weight of onion bulb.

\section{Dry matter percentage of bulb}

There was significant variation of dry matter content of bulb on the effect of different levels of cowdung and potassium. However, it was found that 10 tons cowdung ha-1 and $250 \mathrm{~kg} \mathrm{~K} \mathrm{ha}^{-1}$ produced the maximum dry matter (12.66\%) and minimum dry matter (11.26\%) was recorded under control treatment (Table 2). It was observed that the highest doses of cowdung and potassium as combined cause barrier effect to uptake water by plant.

\section{Yield of bulb per hectare}

The variation in yield at harvest due to the combined effect among different doses of cowdung and potassium was observed to be significant. The maximum yield of bulb (12.83 tons ha-1) was observed with 10 tons cowdung $\mathrm{ha}^{-1}$ and $250 \mathrm{~kg} \mathrm{~K}^{-1} \mathrm{a}^{-1}$ and the minimum yield of bulb (9.16 tons ha-1) was obtained from control treatment (Table 2). Mandaria and Khan (2003) observed similar results and they reported that application of cowdung and potassium showed the best performances in terms of growth and yield.

The present findings revealed that application of 10 ton cowdung ha-1 and $250 \mathrm{~kg} \mathrm{~K} \mathrm{ha}^{-1}$ might be recommended for proper growth and yield of onion cv. BARI piaz-I to get more yield under the Bangladesh Agricultural University, Horticulture Farm conditions. 


\section{References}

Ali, M.Y., Haq, M.F. and Rahman, M.S. 1994. Effect of fertilizer doses on the yield and storability of onion. Bangladesh J. Agril. Sci. 23 (2): 7-12.

Anonymous. 2005. Action plan for increasing the production of spices crop to further $25 \%$, 2005. Ministry of Agriculture, Govt. of the Peoples Republic of Bangladesh. p. 14.

Anonymous.2010.http:// www.slidefinder.net/t/li fe your soil/introductionsoil_microbiology / 11116901. environmental soils.cas.psu.edu.

Brady, N.C. 1995. The Nature and Properties of Soils. Hall of India Pvt. Ltd., New Delhi. p. 369.

Dilruba, S. 2001. Effect of different doses of nitrogen and potassium on growth, yield and storage of onion. MS thesis, Department of Horticulture, Bangladesh Agricultural University, Mymensingh. 58 p.

Gomez, K.A. and Gomez, A.A. 1984. Statistical Procedure for Agricultural Research. (2nd Ed.) J ohn Willey \& Sons, New York. pp. 28192.

Hossain, A.K.M.A. and Islam, J. 1994. Status of Allium production in Bangladesh. Acta Hort. 358: 33-36.

J ones, H.A. and Mann, L.K.1963. Onion and Their Allies. Leonard Hill (books) Ltd., London. p. 32.

Katwale, T.R. and Saraf, R.K. 1994. Studies on response of onion to varying levels of fertilizer doses during monsoon season in Satpura plateau. Orissa J. Hort. 22 (1-2): 9597.

Magruder, R. and Allard, H.K. 1937. Bulb formation in some American and European varieties of onions as affected by length of day. J . Agric. Res. 54: 716-752.

Mandira, C. and Khan, E.B. 2003. Effect of nitrogen and potassium on growth and yield and yield attributes of onion. ICARResearch Conference, India, 14 (1-2): 9-11. [Cited from CAB Abst., 2202/08-2003/10].

Mondal, M.F., Brewster., J.L., Morris, F.E.L. and Butler, H.A. 1986. Bulb development in onion (Allium cepa L.). Effect on plant density and sowing date in field conditions. Ann. Bot. 58 (2): 187-195.

Rai, M.M. 1981. Principles of Soil Science. MacMillan India Limited, Calcutta. pp. 179182.

Shaheen. A., Fatma, M., Rizk, A. and Singer, S. M. 2007. Growing onion plants without chemical fertilization. Res. J. Agr. Biol. Sci., 3 (2): 95-104.

Shalalby, G.L., El-Muraba, A.L., Kandeel, N.M. and Gamie, A. M. 1991. Effect of some cultural practices on onion bulb production from sets at three planting dates, direction of ridges and cultivars. Assiut J . Agril. Sci. 22 (2): 103- 121.

Singh, J. and Dhankhar, S.B. 1989. Effect of nitrogen, potash on growth, yield and quality of onion. Indian Agric. 32 (3): 163170.

Singh, J., Dhankhar, B.S. and Ram, V. 1988. Effect of nitrogen, potash on growth, yield and quality of onion. Veg. Sci. 16 (2): 136144.

Snyman, H.G., Jong, D.E. and Aveling, T.A.S. 1998. The stabilization of sewage sludge applied to agricultural land and the effects on maize seedlings. Water Sci. Tech. 38 (2): 87-95.

Sotomayer, R.J. 1975. Garlic fertilization. Progress Agricola, Chile. 7 (1): 34. [Cited from Hort. Abstr. 47 (1): 53, 1977].

UNDP. 1988. Land Resources. Appraisal of Bangladesh for Agricultural Development Report 2: Agro-ecological Region of Bangladesh. FAO, Rome, Italy. 577 p. 